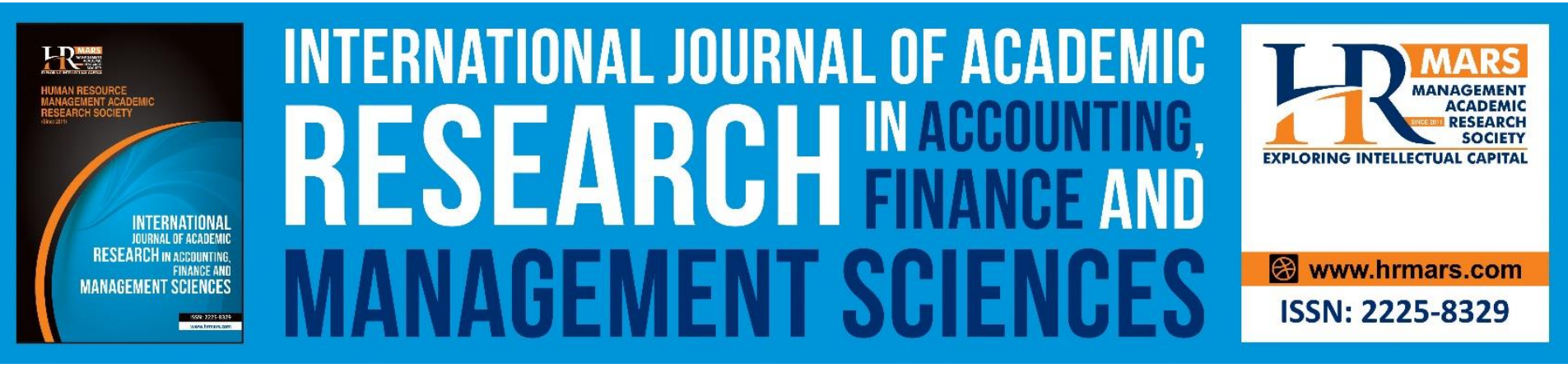

\title{
Comparing Demanded Work Values, and the Relationship between Work Values Congruence and Organizational Commitment between the Gen-X and Gen-Y Employees in Klang Valley, Malaysia
}

Fatimah Wati Halim, Siti Fardaniah Abdul Aziz \& Goh Xin Inn

To Link this Article: http://dx.doi.org/10.6007/IJARAFMS/v11-i3/10808 DOI:10.6007/IJARAFMS /v11-i3/10808

Received: 16 June 2021, Revised: 21 July 2021, Accepted: 29 July 2021

Published Online: 19 August 2021

In-Text Citation: (Halim et al., 2021)

To Cite this Article: Halim, F. W., Aziz, S. F. A., \&, \& Inn, G. X. (2021). Comparing Demanded Work Values, and the Relationship between Work Values Congruence and Organizational Commitment between the Gen-X and Gen-Y Employees in Klang Valley, Malaysia. International Journal of Academic Research in Accounting Finance and Management Sciences, 11(3), 77-93.

Copyright: (C) 2021 The Author(s)

Published by Human Resource Management Academic Research Society (www.hrmars.com)

This article is published under the Creative Commons Attribution (CC BY 4.0) license. Anyone may reproduce, distribute, translate and create derivative works of this article (for both commercial and non-commercial purposes), subject to full attribution to the original publication and authors. The full terms of this license may be seen at: http://creativecommons.org/licences/by/4.0/legalcode

Vol. 11, No. 3, 2021, Pg. 77 - 93

Full Terms \& Conditions of access and use can be found at http://hrmars.com/index.php/pages/detail/publication-ethics 


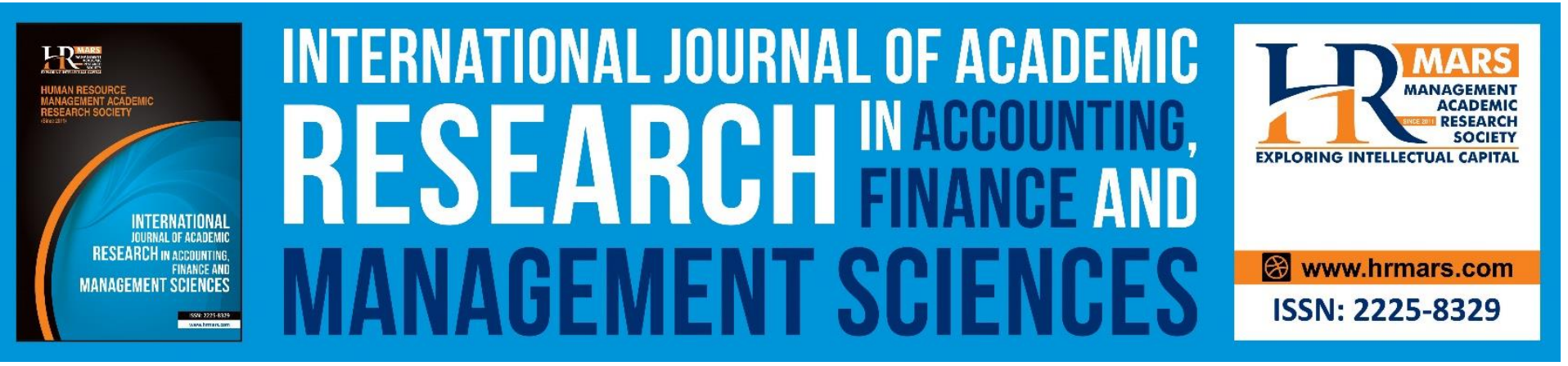

\title{
Comparing Demanded Work Values, and the Relationship between Work Values Congruence and Organizational Commitment between the Gen-X and Gen-Y Employees in Klang Valley, Malaysia
}

\author{
Fatimah Wati Halim, ${ }^{1}$ Siti Fardaniah Abdul Aziz, ${ }^{2}$ \& Goh Xin Inn ${ }^{3}$ \\ ${ }^{1}$ Psychology Program, Psychology \& Human Well-Being Research Centre, Faculty of Social Science \& \\ Humanities, Universiti Kebangsaan Malaysia, Malaysia, ${ }^{2}$ Human Development Program, Psychology \\ \& Human Well-Being Research Centre, Faculty of Social Science \& Humanities, Universiti \\ Kebangsaan Malaysia, Malaysia, ${ }^{3}$ NECOLE Need-based Contextual Learning, Damansara, Selangor \\ Malaysia \\ Email: daniah@ukm.edu.my
}

\begin{abstract}
The purpose of this study was to identify the relationship between work values congruence and organizational commitment as well as to determine the comparison between demanded work values between generation $X(G e n-X)$ and generation $Y(G e n-Y)$ cohort generation staff in the field of Accounting and Finance in the Klang Valley, Malaysia. This is because information regarding workplace diversity is very important to create a better workplace environment in stimulating organizational effectiveness specially to cater on different age among employees. Therefore, this research used a quantitative, survey and purposive sampling involving established instruments; these include Work Value Inventory (WVI), Work Value Congruence Scale (VCS), and the Organizational Commitment Questionnaire (OCQ). The results of Pearson correlation analysis among 169 respondents showed that there was a significant relationship between the work value congruence and organizational commitment $(r=0.617, \mathrm{k} 0.01)$. In addition, a t-test analysis indicated only six dimensions of demanded work values were significantly different between Gen- $Y$ and Gen-X including management, prestige, nature of supervisor, lifestyle, economic returns, and variety of task. From these, Gen-X had higher mean score in management, prestige, nature of supervisor and lifestyle; meanwhile, Gen $Y$ had higher mean score in economic returns and variety of tasks. This research implies that there is a significant difference between Gen-X and Gen- $Y$ in terms of demanded job values; in which, the congruence work values was significantly correlated with organizational commitment. Therefore, employers need to be more careful and vigilant in managing the job behaviour of Gen-X and Gen-Y employees to ensure that both generations can work as a team and sustain a high level of work performance.
\end{abstract}


INTERNATIONAL JOURNAL OF ACADEMIC RESEARCH IN ACCOUNTING, FINANCE AND MANAGEMENT SCIENCES

Vol. 11, No. 3, 2021, E-ISSN: 2225-8329 @ 2021 HRMARS

Keywords: Demanded Work Values, Work Values Congruence, Organizational Commitment, Gen- $X$, Gen-Y, Comparison And Correlational Study, Accounting And Finance, Malaysia

\section{Introduction}

An in-depth understanding of the influence of employees' age and generation on the dimensions of demanded work value, work values congruence and organizational commitment has become increasingly preferred for effective organizational management (Areola, Perono \& llagan, 2021) This is because there were many differences of employees' characteristics from different age groups, such as their working style, decision making and mind-set that will affect organizational performance (Pretti \& McRae, 2021). Hence, these differences should be investigated to understand how organization can improve organizational effectiveness by mixing employees' diversity into a more creative and maximum teamwork.

Historical events and timelines shared by the same generation have shown that employees will share the same work values and views of work (Celikdemir \& Katrinli, 2021). On the other hand, there is an alternative discussion that argues employees in certain organizations have similar views on the value of work regardless of age factors (Yang \& Guy, 2006). Meanwhile, Moses, Ostreicher and Ryan (2010) argue that the new generation has adapted to the transformation of the labour market by increasingly accepting non -traditional jobs such as temporary work, part -time work and multi career. There several studies that reported that generation Y (Gen-Y) employees in the Asia Pacific region have the shortest employment period, such as average of 18 months to 4 years as compared to the generation X (Gen-X) employees (Sheahan \& Sheahan, 2005). According to Roebuck, Smith and Haddaoui (2013), Gen-Y is known as a group of employees who will change jobs in a time period at least 5 years and are difficult to maintain by the organization.

Therefore, the value of work will determine the desire and type of motivation of the employee to be positive and committed to his/her job. Demanded work value is defined by Zedeck, Middlestadt and Hayes (1981) as employees' perceptions of factors related to work content and work environment. Work environment factors such as relationships with colleagues, organizational facilities, extrinsic incentives, employer attitudes and so on are also associated with employee work values. According to White (2006), work value encompasses cognitive, affective and behavioural dimensions that are closely related to workplace satisfaction and motivation. In fact, there are also past studies that have reported that work values carry a significant influence on a variety of employee attitudes and behaviours (Benson \& Brown, 2011).

Further, Gelle-Jimenez and Aguiling (2021) defined the congruence of work value as the congruence between demanded work value desired by employees and the supply of work value required to achieve employees' satisfaction by the organization. Chu and Chu (2013) find that the level of inclination of employees to feel the value of their work with the organization is appropriate to influence attitudes towards work and the organization. According to Vveinhardt and Foktas (2020), work values congruence involves compatibility between individual's work values and organizational work values. Hence, demanded work values can be defined operationally as the component of psychological value or reward found in the workplace and required by an employee as a factor of 
INTERNATIONAL JOURNAL OF ACADEMIC RESEARCH IN ACCOUNTING, FINANCE AND MANAGEMENT SCIENCES

Vol. 11, No. 3, 2021, E-ISSN: 2225-8329 ๑ 2021 HRMARS

motivation and satisfaction with his or her job and organization. Meanwhile the work values congruence can be operationally defined as the degree of congruence of the organization's work value to match the work value that is expected by the employee.

Furthermore, according to Wright (1997), organizational commitment is a work attitude, behavioural purpose, dedication and a strong desire to maintain organizational membership. In addition, Meyer, Allen and Smith (1993) argue that organizational commitment as a reflection of the relationship between employees and the organization and is an antecedent that influences the decision of employees whether to remain or leave the organization. Accordingly, organizational commitment can be perceived as the result of an exchange to the rewards given by the organization to its employees. The reward refers to extrinsic rewards such as promotion, annual bonus, salary increment and so on. A given organizational commitment is influenced by the needs and values of the employees.

On the other hand, generational cohorts refer to groups that have been born in the chronology of the same time period and share historical events, as well as similar social life experiences (Wey-Smola $\&$ Sutton, 2002). The differentiation is based on major life experiences brought to remain stable throughout the course of life development (Wey-Smola \& Sutton, 2002). According to Howe and Strauss (2007), generation refers to a cohort of individuals born at a time when certain political and social events occur, and as a result has influenced development in terms of patterns of values, beliefs, general personalities strong enough to predict and measure. Hence, definition by to distinguish the cohort generation by Brosdahl and Carpenter (2011) is relevant; in which, they argue that Gen-X includes individuals whose years of birth between 1961 to 1981, while Gen-Y includes individuals who were in the group born in 1891 to 1999. Therefore, the purpose of the current research is to identify the comparison between demanded work values, work values congruence, and organizational commitment between the Gen-X and Gen-Y cohort generation staff in the field of Accounting and Finance in the Klang Valley, Malaysia.

In the current research, the dimension of work value is based on the classification determined by Herma et al (1951) and has been divided into two main parts namely intrinsic work value and extrinsic work value. Next, Super and Mowry (1962) has distinguished 15 dimensions of work value in the division of intrinsic work value and extrinsic work value. Meanwhile, demanded work values are divided by Super and Mowry (1962) according to dimensions, and among the dimensions found in intrinsic work value are creativity, management, aesthetics, autonomy, diversity, altruism, and intellectual stimulus. In addition, the dimensions for extrinsic work value are economic return, infrastructure, supervisory nature, teamwork with co-employees, lifestyle, achievement, prestige, and job stability Super and Mowry (1962) also reported four pairs of factors in developing employee work value namely social relationship versus work content, tangible versus intangible, other direction versus self -direction and pleasure versus task -oriented versus.

Further, there are a total of 15 dimensions for demanded work values according to Super and Mowry (1962) and have been applied as subscales in Work Values Inventory (WVI). These include:

(i) Creativity; which is referred as the work that allows employees to generate ideas or design new products. 
INTERNATIONAL JOURNAL OF ACADEMIC RESEARCH IN ACCOUNTING, FINANCE AND

MANAGEMENT SCIENCES

Vol. 11, No. 3, 2021, E-ISSN: 2225-8329 @ 2021 HRMARS

(ii) Management; which is referred as the work that allows employees to plan tasks, supervise and manage other employees.

(iii) Achievements; which is referred as the work that gives satisfaction of success because of achieving or doing a task well.

(iv) Infrastructure; which is referred as the work that provides a conducive and comfortable workplace, as well as having infrastructure facilities.

(v) Nature of supervisor; which is referred as the work carried out under a fair supervisor, of good character and having a good relationship with employees.

(vi) Lifestyle; which is referred as the work that allows the employee to have the lifestyle and type of individual he or she desires, as well as to have a balance in work and life.

(vii) Job stability; which is referred as the work that provides psychological security in the form of job security and positions held despite the economic downturn in the future.

(viii) Peer relationships; which is referred as the work that supported by colleagues at the same workplace.

(ix) Aesthetics; which is referred as the work that allows employees to produce something beautiful and contribute beauty to the world.

(x) Prestige; which is referred as the work that allows employees to earn the respect of others in the form of status and power.

(xi) Autonomy; which is referred as the work that allows a person to work following his own way and speed.

(xii) Variety of tasks; which is referred as the work that gives employees the opportunity to perform tasks that keep changing and have diverse characteristics.

(xiii) Economic returns; which is referred as the work that offers a lucrative wage reward and allows the employee to purchase the desired material goods.

(xiv) Altruism; which is referred as the work that allows employees to contribute to the welfare of others.

(xv) Intellectual stimulus; which is referred as the work that allows employees to think critically who have a stand -up and learn new knowledge.

Gen-X went through economic instability in the early 1980s and social instability such as parental divorce in the early developmental period (Lyons, Urick, Kuron \& Schweitzer, 2015). Most of them have gone through experiences like both working parents, and some have also gone through domestic divorce. As a result of the following experiences, most of this generation has become more independent since a young age. Gen-X has been described as a generation that has always felt socially insecure and lacked a strong tradition (Barford \& Hester, 2011). Gen-X also tends to have social skills that are not as good as their parents but have high technical abilities (Shaw \& Fairhurst, 2008). Employees who belong to Gen-X will do tasks quickly and smartly, and they can accept themselves breaking the rules or taking shortcuts (Eisner, 2005). A lifestyle that embraces cultural diversity and global views has become the norm among Gen-X (Williams \& Page, 2011). The main characteristic features that contribute to the values of Gen-X are individualism, self -reliance, autonomy (Gursoy, Maier \& Chi, 2008) and sceptical (Crumpacker \& Crumpacker, 2007).

In contrast to Gen-X, Gen-Y was born in an era of booming economies, the great emergence of social media and reality television programs, as well as the loss of modernist values supported by 
INTERNATIONAL JOURNAL OF ACADEMIC RESEARCH IN ACCOUNTING, FINANCE AND

MANAGEMENT SCIENCES

Vol. 11, No. 3, 2021, E-ISSN: 2225-8329 @ 2021 HRMARS

internalization and the strong influence of pop culture (Parment, 2011). Gen-Y is highly confident, optimistic and feels that itself holds the power to take remedial action when problems arise. Individuals from this generation cohort also have the skills to perform multiple tasks at the same time, are technologically competent, casual and fun -loving (Gursoy et al., 2008). Majority of their daily lives and activities are regulated by digital technology, social interaction, friendships and civic activities. Hence, comparing the characteristics of demanded work values, work values congruence and organizational commitment among Gen-X and Gen-Y is very important to create a better environment to optimize organizational effectiveness.

\section{Literature Review}

\section{Work Values Congruence with Organizational Commitment}

Based on a study conducted by Eker and Pala (2008), work value factors such as work environment, organizational management system, income, job security and workplace facilities have a significant impact on organizational commitment. According to a study by Lub, Bijvank, Bal, Blomme and Schalk (2012), contract psychology can be understood as an employee's belief about the value of work's worthy awarded by the organization as a return for their workforce contributions. Meanwhile, Blau (1968) argue that psychological contracting has been explained in Social Exchange Theory, which suggests that employees and organizational parties engage in exchanges in which employee contributions will be reciprocated by a factor of work value given by the organization. Dissatisfaction in the value of work will result in employees feeling unbalanced in psychological contracts, causing employees to balance those rewards with reduced contributions, involvement and commitment to the organization. Thus, previous study conducted by Bal, De-Cooman and Mol (2013) and Conway and Briner (2005) has stated that job value satisfaction carries a strong influence on organizational commitment.

\section{Differences in Demanded Work Values and Work Values Congruence by Generation Cohort (Gen-X and Gen-Y)}

In the study of 'Generational Differences in Work Values, Outcomes and Person- organisation Values Fit' by Lucy and Dianne (2008), work value was measured based on two research tools, which were Work Values Questionnaire (WVQ) by Elizur (1984) and Work Values Scale (WVS) by Lyons (2004). The WVQ research tool consists of four work value factors, namely extrinsic, altruistic, intrinsic and status, while WVS has added freedom and social factors as work value factors. Their study has found that Gen-Y group employees are more concerned with the work value of independence factor than Gen-X employees. In addition, it has been found that Gen-Y places high importance on autonomy factor and work-life balance factor. On the other hand, the Gen-X group will be likely to leave the organization if the work value factors of freedom and autonomy cannot be satisfied. Nevertheless, there were no significant differences between the generation group and the other four work value factors.

According to Ng and Feldman (2011) differences between Gen-X and Gen- $Y$ will also influence the work values and expectations of that generation group towards their organization. In addition, Bal et al. (2013) also suggests that some work value factors are related to employees' age. Nonetheless, since most studies of psychological contracting are longitudinal in nature, there are no study findings that can prove whether differences in work values between generational groups are influenced by 
INTERNATIONAL JOURNAL OF ACADEMIC RESEARCH IN ACCOUNTING, FINANCE AND MANAGEMENT SCIENCES

Vol. 11, No. 3, 2021, E-ISSN: 2225-8329 ๑ 2021 HRMARS

the effects of aging or differences in generational views. According to the studies conducted by McDonald and Hite (2008), differences in generational groups also impact the overall management of the organization, including the hiring process, training, career development, rewards and management practices. To refute the statement arguing that differences in work values of different generational groups are due to emotional development according to age maturity, Wey-Smola and Sutton (2002) have found that values held are more influenced by the collective experience of generations, not biological age. Moreover, Parry and Urwin (2011) in their longitudinal studies have found that the value of work is more influenced by the experience of generations collectively than by biological age.

\section{Differences in Organizational Commitment by Generation Cohort (Gen-X and Gen-Y)}

The study 'Explaining Generation Y Employees' Turnover in Malaysian Context' conducted by Queiri, Yusoff and Dwaikat (2015) has confirmed the statement information about the phenomenon of Gen$Y$ employees who often decide to leave the company. Using the Three -Component Model of Organizational Commitment put forward by Allen Meyer and (1990), their study finds that there are three types of organizational commitment, namely ongoing commitment, normative commitment and affective commitment. However, their study only focuses on normative type organizational commitment, as normative commitment is referred to as a sense of responsibility to pursue membership as an employee of their organization in line with the purpose of this study.

Further a recent cross -sectional study by Kapoor and Solomon (2011) has proven that Gen-Y employees have the lowest level of organizational commitment as compared to Gen- $X$, especially in normative commitment. Additionally, study by Solnet and Hood (2008) has also proven that the $Y$ Gen group has the lowest ranking in normative commitment. Taken together, researchers argue that normative commitment is influenced by family factors and societal norms and has developed in employees before joining the organization again. This has proven that normative commitment is influenced by the worldview that has been cultivated as a result of environmental factors belonging to a particular generation group. Past studies by Myers and Sadaghiani (2010) have also shown a lack of normative commitment attitudes among Gen-Y.

\section{Methodology}

\section{Research Procedure}

The current research used quantitative and survey questionnaires that were distributed to respondents who are currently working in accounting and financial field at several organizations in Klang Valley, Malaysia. Questionnaires were distributed to organizations that have accounting and finance employees during office hours around the Klang Valley area, Selangor and around cafes near the office during office breaks. It is estimated that at least 40 offices of the organization around Lingkaran Syed Putra, Pusat Bandar Damansara, SS 15 Subang Jaya, Taipan USJ and USJ 9 were invited as respondents. Before distributing the questionnaire to employees in the organization, the researcher will ask permission from the Human Resource Manager or from the administration officer at the organizations. There is no time limit to complete the questionnaire and the questionnaire can be completed within 15 minutes; respondents will be given a day to return the questionnaire. 
INTERNATIONAL JOURNAL OF ACADEMIC RESEARCH IN ACCOUNTING, FINANCE AND MANAGEMENT SCIENCES

Vol. 11, No. 3, 2021, E-ISSN: 2225-8329 @ 2021 HRMARS

\section{Population and Study Sample}

The current research population consisted of accounting and financial field employees that were currently working in the Klang Valley and were Gen-X (born in 1961 1981) or Gen-Y (born in 1981 1999) using definition given by Brosdahl and Carpenter (2011). A total number of 200 questionnaires were distributed during office hours, and a total of 169 data $(N=169)$ were collected from respondents who were employees in 40 organizations Klang Valley, Malaysia. This study used purposive sampling method, in which only employees in the fields of accounting and finance were selected.

\section{Research Instrument}

The instrument used in the current research were adapted from Work Values Inventory/WVI (Super \& Mowry, 1962) that comprised of 45 items, Value Congruence Scale (VCS) adapted from Cable and Edwards (2004) that comprised of 11 items, and Organizational Commitment Questionnaire (OCQ) (Mowday \& Steers, 1979) that comprised of 15 items. There are four sections in the questionnaire including demographic profile section (Section A), demanded work values section (Section B), work values congruence section (Section $C$ ) and organizational commitment section (Section $D$ ).

\section{Demographic Profile}

This section contains 6 items related to respondents' personal information such as gender, generation group, duration of employment, academic qualifications, monthly income and job position. This section provides the researcher with information relevant to the demographic profile of the respondents.

\section{Work Values Inventory (WVI)}

The Work Values Inventory (WVI) questionnaire designed by Super and Mowry (1962) was used in the research. All of the items in the WVI measured the importance of the dimensions given by the organization to respondents' satisfaction in the workplace. In addition, this questionnaire also measured the value of work that provides job satisfaction and job satisfaction obtained after performing a certain type of work. The questionnaire comprised of 45 items; this includes 15 dimensions of work value with each dimension contained 3 questions. The value of work in WVI developed by Super and Mowry (1962) is divided into intrinsic work value and extrinsic work value. The dimensional dimensions for intrinsic work value are 'creativity', 'management', 'aesthetics', 'autonomy', 'diversity', 'altruism', and 'intellectual stimuli. in contrast, extrinsic work values consist of 'economic return', 'infrastructure', 'supervisory nature', 'teamwork with colleagues', 'lifestyle', 'achievement', 'prestige', and 'job stability'. The questionnaire consisted of all positive items and had a choice of 5 -point Likert scale, namely 'Very Important', 'Important', 'Not Sure', 'Not Important' and 'Very Not Important'. In this study, the Cronbach's alpha value for WVI was very high at 0.837.

\section{Value Congruence Scale (VCS)}

Value Congruence Scale (VCS) questionnaire was used and adapted from the items developed by Cable and Edwards (2004); the VCS was designed to measure the degree of appropriateness or congruence of the respondent's work value with his or her organizational value. This questionnaire had 11 items, including 8 positive items and 3 negative items. It also used a 5 -point Likert scale, namely 'Strongly Agree', 'Agree', 'Not Sure', 'Disagree' and 'Strongly Disagree'. Positive items and 
INTERNATIONAL JOURNAL OF ACADEMIC RESEARCH IN ACCOUNTING, FINANCE AND

MANAGEMENT SCIENCES

Vol. 11, No. 3, 2021, E-ISSN: 2225-8329 @ 2021 HRMARS

negative items have been mixed. In this study, the consistency reliability value in Cronbach's Alpha for VCS was 0.837.

\section{Organizational Commitment Questionnaire (OCQ)}

The Organizational Commitment Questionnaire (OCQ) designed by Mowday and Steers (1979) was adapted to measure the level of respondents 'commitment to their organization. This questionnaire is related to respondents 'perceptions of their loyalty to the organization, willingness to contribute more energy to achieve organizational goals and their acceptance of organizational values. The questionnaire consists of 15 items, namely 9 positive items and 6 negative items. In this research, a 5 -point Likert scale as conducted in the study of Marion et al. (1995) was used, namely 'Strongly Agree', 'Agree', 'Not Sure', 'Disagree' and 'Strongly Disagree'. In this study, it was found that the Cronbach's alpha value for the Organizational Commitment Questionnaire (OCQ) questionnaire was high at 0.73 .

\section{Data Analysis}

Data collected were analysed using Statistical Package for Social Sciences (SPSS version 20.0). The use of SPSS can avoid errors when analysing data. The analyses that have been performed was t-test at 0.05 level of significant. The t-test was used to achieve research objective.

\section{Research Findings}

Findings of Descriptive Statistic

Work Values Inventory (WVI)

The highest mean for WVI was the Supervisor Trait dimension which was 13.39 (standard deviation = 1.78). In contrast, Aesthetics achieved the lowest mean with 9.92 (standard deviation = 2.25). In addition, the highest minimum score was 6 achieved by Job Stability and Peer Relations, while the lowest minimum score was 3 and achieved by Autonomy. The maximum score for all 15 dimensions was the same which was 15.

\section{Value Congruence Scale (VCS)}

The results of VCS showed respondents' perceptions of the level of congruence between the value of self -work and the value of organizational work. The mean for Work Values Congruence was 44.11 while the standard deviation was 4.40. The minimum score for Work Values Congruence was 26 while the maximum score was 52.

\section{Organizational Commitment Questionnaire (OCQ)}

Using OCQ, result indicated that respondents' perceptions mean level of Work Values Congruence was 44.11 while the standard deviation was 4.40. The minimum score for Organizational Commitment was 25 while the maximum score was 74 .

Findings indicated that there was a significant correlation between the work values congruence and organizational commitment for both Gen-X and Gen-Y. It was found that the work value congruence had a positive relationship with organizational commitment with $r=0.617, p=0.01$. 
INTERNATIONAL JOURNAL OF ACADEMIC RESEARCH IN ACCOUNTING, FINANCE AND MANAGEMENT SCIENCES

Vol. 11, No. 3, 2021, E-ISSN: 2225-8329 @ 2021 HRMARS

\section{Findings of Inferential Statistic}

Further, t-test analysis indicated significant differences for several dimensions of demanded work values among Gen-X and Gen-Y employees. Referring to table 1 shown below, a t-test was organized on 15 dimensions of demanded work value between Gen-X and Gen-Y.

Table 1: Mean, Standard Deviation, $t$-Value and Significance of Demanded Work Value between Gen$X$ and Gen-Y Employees

\begin{tabular}{|c|c|c|c|c|c|c|}
\hline Dimension & $\begin{array}{c}\text { Generational } \\
\text { Cohort }\end{array}$ & $\mathrm{N}$ & Mean & $\begin{array}{l}\text { Standard } \\
\text { Deviation }\end{array}$ & $\mathrm{t}$ & $p$ \\
\hline \multirow[t]{2}{*}{ Creativity } & Gen-X & 84 & 10.39 & 2.10 & -3.134 & 0.378 \\
\hline & Gen-Y & 85 & 12.15 & 4.70 & & \\
\hline \multirow[t]{2}{*}{ Management } & Gen-X & 84 & 10.77 & 1.75 & 0.706 & 0.011 \\
\hline & Gen-Y & 85 & 10.55 & 2.28 & & \\
\hline \multirow[t]{2}{*}{ Achievement } & Gen-X & 84 & 11.61 & 1.95 & -3.426 & 0.457 \\
\hline & Gen-Y & 85 & 12.58 & 1.72 & & \\
\hline \multirow[t]{2}{*}{ Infrastructure } & Gen-X & 83 & 13.10 & 2.16 & 3.482 & 0.413 \\
\hline & Gen-Y & 85 & 12.00 & 1.91 & & \\
\hline \multirow{2}{*}{$\begin{array}{l}\text { Nature of } \\
\text { Supervisor }\end{array}$} & Gen-X & 84 & 13.92 & 1.62 & 3.994 & 0.038 \\
\hline & Gen-Y & 85 & 12.87 & 1.78 & & \\
\hline \multirow[t]{2}{*}{ Lifestyle } & Gen-X & 84 & 11.71 & 1.54 & -2.043 & 0.047 \\
\hline & Gen-Y & 85 & 12.26 & 1.90 & & \\
\hline \multirow[t]{2}{*}{ Work Stability } & Gen-X & 84 & 13.38 & 1.88 & 6.825 & 0.176 \\
\hline & Gen-Y & 85 & 11.27 & 2.14 & & \\
\hline Peer & Gen-X & 84 & 9.67 & 2.06 & -6.269 & 0.958 \\
\hline Relationships & Gen-Y & 85 & 11.60 & 1.95 & & \\
\hline \multirow[t]{2}{*}{ Aesthetics } & Gen-X & 84 & 9.75 & 2.08 & -9.60 & 0.102 \\
\hline & Gen-Y & 85 & 10.08 & 2.41 & & \\
\hline \multirow[t]{2}{*}{ Prestige } & Gen-X & 84 & 11.61 & 1.40 & 0.989 & 0.000 \\
\hline & Gen-Y & 85 & 11.32 & 2.30 & & \\
\hline \multirow[t]{2}{*}{ Autonomy } & Gen-X & 84 & 10.55 & 1.80 & -2.155 & 0.186 \\
\hline & Gen-Y & 85 & 11.17 & 1.92 & & \\
\hline \multirow[t]{2}{*}{ Variety of Tasks } & Gen-X & 84 & 11.23 & 1.77 & -0.193 & 0.050 \\
\hline & Gen-Y & 85 & 11.28 & 2.00 & & \\
\hline Economic & Gen-X & 84 & 12.25 & 1.54 & -1.401 & 0.001 \\
\hline Returns & Gen-Y & 85 & 12.62 & 1.91 & & \\
\hline \multirow[t]{2}{*}{ Altruism } & Gen-X & 84 & 9.89 & 2.44 & -4.975 & 0.559 \\
\hline & Gen-Y & 85 & 11.72 & 2.33 & & \\
\hline Intellectual & Gen-X & 84 & 10.71 & 2.02 & -2.806 & 0.495 \\
\hline Stimulus & Gen-Y & 85 & 11.58 & 1.97 & & \\
\hline
\end{tabular}

Findings indicated that only 6 dimensions of demanded work values including economic returns and variety of tasks were significantly higher among Gen-Y as compared to Gen-X. Additionally, aspects of management, prestige, nature of supervisor, and lifestyle were significantly higher among Gen-X 
INTERNATIONAL JOURNAL OF ACADEMIC RESEARCH IN ACCOUNTING, FINANCE AND MANAGEMENT SCIENCES

Vol. 11, No. 3, 2021, E-ISSN: 2225-8329 @ 2021 HRMARS

as compared to Gen-Y. Meanwhile, other dimensions of demanded work values including creativity, achievement, infrastructure, work stability, peer relation, altruism, peer relations, aesthetics and autonomy were not significantly different between Gen-X and Gen-Y.

The mean value for work values congruence among respondents was 46.43 (SP $=2.56$ ) for Gen-X employees and 41.84 (SP = 4.66) for Gen-Y employees. This indicated that the mean of Gen-X employees in work values congruence was higher than that of Gen-Y employees. In addition, there was a significant difference between the work values congruence of Gen-X and Gen-Y employees' work values [ $t=7.931, p=0.000]$. Thus, there was a significant difference between the work values congruence of Gen-X and Gen-Y employees. The value of $p$ indicated a significant level at 0.005.

Finally, a t-test was also performed to determine significant difference between organizational commitment of Gen-X and Gen-Y employees. The mean value for the level of organizational commitment was 51.35 ( $\mathrm{SP}=5.92$ ) for Gen-X employees and 48.53 (SP = 8.56) for employees Gen-Y. This indicated that the mean of Gen-X employees in terms of level of commitment was higher than the mean of Gen-Y employees [ $t=2.504, p=0.003]$.

\section{Discussion}

Findings found a significant relationship between the work value congruence and organizational commitment. Findings of this research was supported by previous study including by Nick (1990), who found that the work values congruence and organizational rewards had a significant relationship with organizational commitment. Additionally, according to Twenge et al (2010) as well, the work values congruence can have a major impact on employees 'desire to leave the organization at the organizational level. In general, the work values congruence has been seen as having a greater impact on organizational commitment than factors such as length of employment, academic qualifications and income (Nick, 1990). Variables such as high organizational commitment and loyalty to the organization will often be associated with the congruence between individual work values and organizational values.

Findings also indicated that only 6 dimensions of demanded work values were significantly different between Gen-Y and Gen-X; in which economic returns and variety of tasks were significantly higher among Gen-Y, and aspects of management, prestige, nature of supervisor and lifestyle were significantly higher among Gen-X. Findings is supported by previous researches. For example, Gursoy et al (2008) found that Gen-X was more rebellious towards upper party management and was reluctant to receive instructions from their supervisors; in which, Gen- $Y$ was more to place high trust and respect in the management of the organization. Thus, Gen-Y was a better follower but Gen-X was a better leader.

Further, Twenge et al (2010) found that Gen-Y was more concerned with the value of work that provides a fun and good lifestyle. Gen-Y will be more likely to make career choice decisions based on lifestyle and recreation as compared to advances in career construction. The Y generation is also more concerned with work-life balance than previous generations. Gursoy et al. (2008) also found that Gen-X was more inclined to befriend highly prestigious groups at the organizational level. 
INTERNATIONAL JOURNAL OF ACADEMIC RESEARCH IN ACCOUNTING, FINANCE AND MANAGEMENT SCIENCES

Vol. 11, No. 3, 2021, E-ISSN: 2225-8329 @ 2021 HRMARS

Furthermore, according to a study by Queiri et al (2015), Gen-Y prefers different tasks and gives exposure from more types of tasks in order to feel pleasure from the job. This can be explained by the nature of Gen-Y which is more concerned with holistic exposure than unchanging, static and nondynamic occupations. This is also consistent with the study of Lyons et al (2015), who found that Gen$Y$ has a higher level of career mobility than Gen-X. Gen- $Y$ is also a group that values career development and improvement through job-hopping and change their job more frequently to gain new skills and exposure opportunities. Gen-Y was also found to have a high economic return demanded work values as compared to Gen-X. The findings of this study were consistent with Queiri, et al. (2015) who stated that extrinsic reward is more important by Gen-Y compared to other work value dimensions, especially in the Malaysian context. Additionally, Weyland (2011) found that Gen$Y$ was not concerned with prestige and status of work values. Gen-Y have watched their dedicated parents work for prestige such as promotion to the point of neglecting life and family; hence, Gen-Y was found to be more concerned with the task value dimension of task diversity as compared to Gen$\mathrm{X}$.

Rewards in the form of economic returns by Gen-Y employees in Malaysia have been further strongly supported by the study of Ching and Kee (2012); in which they found that there was a significant difference in the work values congruence between Gen-X and Gen-Y employees. These findings were also consistent with the study by Alexander and Liudmila (2016); in which, the researchers found that several factors including age and life experience contribute significant different on the congruence of perceived work values. Alexander and Liudmila (2016) also found that those who were married, had children and took management level positions would have a high perception of the work values congruence. Statistically, employees who were aged 30 to 35 years and categorized as Gen- $Y$, and had an employment period of 6 to 10 years had a higher perception of work values congruence (Alexander \& Liudmila, 2016).

Results also indicated that there was a difference in terms of level of commitment between Gen-X employees and Gen-Y employees. The magnitude of these organizational level differences was large, with Gen-Y having twice as much job exchange rate as Gen-X. In addition, changes in job mobility trends and organizations by generation were evidenced by the fact that Gen-X also faced double job exchange two times more than the previous generation, such as the Baby Boomers. According to Lyons et al. (2015), the organizational legacy rate and level of mobility by Gen-Y were significantly higher than Gen-X. However, based on an assessment of the total score range for both generations, the current research found that although Gen-X had a higher level of organizational commitment than Gen-Y, Gen-Y actually had a relatively high score range in the level of organizational commitment, such as a moderate level. Thus, this study dispelled the stereotype that the new generation especially Gen-Y had a low level of commitment.

\section{Research Implication and Recommendation}

Although there are many studies that have examined generational cohort differences between Gen$X$ and Gen- $Y$ in work values and other work cultures, not many studies have been conducted on generational differences among Accounting and Finance field among employees. Moreover, the findings of previous studies are very diverse although there are many studies related to generational 
INTERNATIONAL JOURNAL OF ACADEMIC RESEARCH IN ACCOUNTING, FINANCE AND

MANAGEMENT SCIENCES

Vol. 11, No. 3, 2021, E-ISSN: 2225-8329 ๑ 2021 HRMARS

differences in the workplace. This has led to research recommendations suggesting that more research on the impact of generational differences in the workplace could be done.

For practical implications, the findings of this study have supported previous studies that examined generational differences in the need for work value, work values congruence and organizational commitment. According to Abdullah, Omar, Rahman and Adham (2013), work values among employees is very important because it determines how employees value their own organization. Meanwhile, Abdin, Ismail and Muhamad (2019) find that employees' work value determines their organizational commitment. In fact, Rasip et al (2020) find that it is important to maintain high level of organizational commitment because it affects employees' turn over; in which, high rate of turnover gives negative impacts to organizational effectiveness. In addition, Hamidaton, Lee, Ismail, Shahida and Sanusi (2018) demonstrate the importance of employees' work values and congruence as predictor for organizational commitment.

Furthermore, this study has corrected some misconceptions or stereotypes about the new generation of employees namely Gen-X and Gen-Y who achieve moderately high mean for their level of commitment to the organization. There are several dimensions of demanded work value of this study that were found to differ between Gen-X and Gen-Y such as management dimensions, supervisor nature, lifestyle, prestige, variety of tasks and economic return. Some of these work value dimensions highlighted that Gen-Y appreciate extrinsic work value more than Gen-X. Hence, organizational management can benefit from this study by applying strategies to retain Gen-X and Gen-Y employees in the organization by understanding their work value needs from the grassroots.

Moreover, as a result of the practical implications of the study, it is recommended to the management of the organization to stimulate open communication among employees with different generations about the value of the work that is indispensable to them. The field of Accounting and Finance is an intensive field and has a relatively heavy workload, especially during certain seasons. Therefore, the psychological health of employees should be taken into account by making them feel that their welfare is important to the organization in order to increase the level of commitment and the level of work values congruence to the organization. Hence, future researchers and practitioners can focus on the six dimensions of demanded work values including economic returns, variety of tasks, management, prestige, nature of supervisor and lifestyle to create a better workplace diversity collaboration between different age generations especially between Gen X and Gen Y. These six dimensions can be developed among various generations of employees through employees' training and development program (Aziz, 2018). In fact, suitable training program is indicated to guarantee organizational effectiveness (Aziz et al., 2021). Since the world have been experience pandemic COVID 19, it is recommended to organize e-training because Moradi, Mohamed and Yahya (2018) find that e-training is effective as traditional training to improve employees' work values. Additionally, Ibrahim, Halim, Sulaiman and Ibrahim (2020) demonstrated the importance of nurturing employees' work values to fit in organization in order to increase organizational commitment.

\section{Research Limitation}

The limitation of this study is that the cross -sectional study design does not allow this study to identify whether the differences between Gen-X and Gen-Y are due to career development phase, 
INTERNATIONAL JOURNAL OF ACADEMIC RESEARCH IN ACCOUNTING, FINANCE AND MANAGEMENT SCIENCES

Vol. 11, No. 3, 2021, E-ISSN: 2225-8329 @ 2021 HRMARS

life development phase or generational cohort factors that do have differences. Hence it is suggested for future researchers to consider important criterion including the maturity level, work experience and passage of time among respondents. In addition, the work value congruence is also a mutual adjustment adjusted between two parties, namely individuals and organizations that should be consider by future researcher. A further limitation of the study is that this study cannot be generalized to all areas of Gen-X and Gen-Y employees because the population of this study has been specified to Accounting and Finance employees only using purposive sampling. Moreover, the conclusions of this study were based on a limited sample, namely 169 respondents in 40 organizations in Klang Valley, Malaysia. Therefore, the generalization capability of this study was limited by a small sample size.

\section{Conclusion}

In conclusion, there are several significant findings including a significant relationship between work values congruence and organizational commitment, and significant difference between Gen- $X$ and Gen-Y employees in Accounting and Financial job field in several dimensions of demanded work values; this includes management dimensions, supervisor nature, lifestyle, prestige, variety of tasks and economic return. Furthermore, it is expected that this study will provide contributions and implications in the application of strategies of strengthening the new work values congruence and new demanded work values by the next generation of new employees. Hence, these dimensions of demanded work values, work values congruence, and organizational commitment should be focussed on to stimulate better organizational effectiveness within age diversity among employees in the Accounting and Financial job field.

\section{Acknowledgement}

The research is a part of student's thesis research. Special thanks to Universiti Kebangsaan Malaysia that supported the research under Strategic Action Research Grant (PTS-2013-047) as extension study and Strategic Research Grant (KRA-2018-026).

\section{References}

Abdin, F., Ismail, A., \& Muhamad, N. S. A. (2019). Relationship between Distributive Fairness in Remuneration Systems and Organizational Affective Commitment with Trust in Supervisors as Mediator. International Journal of Business \& Management Science, 9(3).

Abdullah, N. A., Omar, F., Rahman, N. M. N. A., \& Adham, K. A. (2013). Conceptualizing work and organizational values from the Islamic perspective. Jurnal Pengurusan (UKM Journal of Management), 39.

Alexander \& Liudmila. (2016). Work-related factor that affect organisational commitment: An examination using Millienials in the Workforce of Thailand. International Journal of Research in Business Studies and Management 3(11): 33-42.

Allen, N. J., \& Meyer, J. P. (1990). The measurement and antecedents of affective, continuance and normative commitment to the organization. Journal of Occupational Psychology, 63(1), 1-18.

Areola, E. M. Q., Perono, I. R., \& Ilagan, J. C. (2021). The Need for Intervention for Psychological WellBeing (PsWB) of Gen-Y Employees in Selected Business Process Outsourcing in the Philippines. Journal of Sustainable Community Development (JSCD), 3(1), 29-49. 
INTERNATIONAL JOURNAL OF ACADEMIC RESEARCH IN ACCOUNTING, FINANCE AND

MANAGEMENT SCIENCES

Vol. 11, No. 3, 2021, E-ISSN: 2225-8329 @ 2021 HRMARS

Aziz, S. F. A. (2018). Keberkesanan latihan dan pembangunan sumber manusia. Bangi, Selangor: Penerbit UKM.

Aziz, S. F. A., Halim, F. W., Mohd, R. H., Selamat, M. N., Omar, N. H., Ibrahim, A., \& Derasol, M. Y. (2021). Nurturing organizational characteristics to maximize training impact on teamwork effectiveness: The Malaysian sample. International Journal of Academic Research in Economics and Management and Sciences, 10(1), 223-243.

Bal, P. M., De-Cooman, R., \& Mol, S. T. (2013). Dynamics of psychological contracts with work engagement and turnover intention: The influence of organizational tenure. European Journal of Work and Organizational Psychology, 22(1), 107-122.

Barford, I. N., \& Hester, P. T. (2011). Analysis of generation $Y$ workforce motivation using Multiattribute Utility Theory. Defense Acquisition Univ Ft Belvoir Va.

Benson, J., \& Brown, M. (2011). Generations at work: are there differences and do they matter? The International Journal of Human Resource Management, 22(9), 1843-1865.

Blau, P. M. (1968). Social exchange. International Encyclopaedia of The Social Sciences, 7, 452-457.

Brosdahl, D. J., \& Carpenter, J. M. (2011). Shopping orientations of US males: A generational cohort comparison. Journal Of Retailing and Consumer Services, 18(6), 548-554.

Cable, D. M., \& Edwards, J. R. (2004). Complementary and supplementary fit: a theoretical and empirical integration. Journal of Applied Psychology, 89(5), 822.

Celikdemir, D. Z., \& Katrinli, A. (2021). Efficient Diversity Management for Workplace Well-Being. The Palgrave Handbook of Workplace Well-Being, 65-85.

Ching, S., \& Kee, D. (2012). Work values-career commitment relationship of generation y teachers in Malaysia. In International Conference on Economics Marketing and Management (Vol. 28, pp. 242-246).

Chu, A. Z., \& Chu, R. J. (2013). Service willingness and senior tourists: knowledge about aging, attitudes toward the elderly, and work values. The Service Industries Journal, 33(12), 11481164.

Conway, N., \& Briner, R. B. (2005). Understanding psychological contracts at work: A critical evaluation of theory and research. Oxford University Press.

Crumpacker, M., \& Crumpacker, J. M. (2007). Succession planning and generational stereotypes: should HR consider age-based values and attitudes a relevant factor or a passing fad? Public Personnel Management, 36(4), 349-369.

Elizur, D. (1984). Facets of work values: A structural analysis of work outcomes. Journal of Applied Psychology, 69(3), 379.

Eisner, S. P. (2005). Managing generation Y. SAM Advanced Management Journal, 70(4), 4.

Eker, M., Eker, S., \& Pala, F. (2008). The effects of job satisfaction on organizational commitment among turkish health care staff an empirical study. Journal of Academic Studies, 10(36), 46-68.

Gelle-Jimenez, M., \& Aguiling, H. M. (2021). Leveraging human resources management (HRM) practices toward congruence of values. International Journal of Research in Business and Social Science (2147-4478), 10(1), 85-94.

Gursoy, D., Maier, T. A., \& Chi, C. G. (2008). Generational differences: An examination of work values and generational gaps in the hospitality workforce. International journal of hospitality management, 27(3), 448-458.

Hamidaton, U., Lee, M. S., Ismail, A., Shahida, N., \& Sanusi, A. (2018). Ethical climate as a determinant of organizational commitment. International Journal of Asian Social Science, 8(8), 534-539. 
INTERNATIONAL JOURNAL OF ACADEMIC RESEARCH IN ACCOUNTING, FINANCE AND

MANAGEMENT SCIENCES

Vol. 11, No. 3, 2021, E-ISSN: 2225-8329 @ 2021 HRMARS

Herma, J. L. V., Ginsburg, S. W., Axelrad, S., Ginzberg, E., \& Herma, J. L. (1951). Occupational choice. In Occupational Choice. Columbia University Press.

Howe, N., \& Strauss, W. (2007). The next 20 years: how customer and workforce attitudes will evolve. Harvard Business Review, 85(7-8), 41-52.

Ibrahim, A., Halim, F. W., Sulaiman, W. S. W., \& Ibrahim, M. A. (2020). The role of organizational citizenship behavior as a mediator in the effect of work passion factors on organizational commitment among teachers in Selangor. International Journal of Psychosocial Rehabilitation. 24 (4), 4268-4287

Kapoor, C., \& Solomon, N. (2011). Understanding and managing generational differences in the workplace. Worldwide Hospitality and Tourism Themes, 3(4), 308.

Lub, X., Bijvank, M. N., Bal, P. M., Blomme, R., \& Schalk, R. (2012). Different or alike? Exploring the psychological contract and commitment of different generations of hospitality workers. International Journal of Contemporary Hospitality Management 24(4): 553-573.

Lucy, C. \& Dianne, G. (2008). Generational differences in work values, outcomes and personorganisation values fit. Journal of Managerial Psychology 23(8): 891-906.

Lyons, S. (2004). An exploration of generational values in life and at work (Doctoral dissertation, Carleton University).

Lyons, S., Urick, M., Kuron, L., \& Schweitzer, L. (2015). Generational differences in the workplace: There is complexity beyond the stereotypes. Industrial and Organizational Psychology, 8(3), 346-356.

McDonald, K. S., \& Hite, L. M. (2008). The next generation of career success: Implications for HRD. Advances in Developing Human Resources, 10(1), 86-103.

Meyer, J. P., Allen, N. J., \& Smith, C. A. (1993). Commitment to organizations and occupations: Extension and test of a three-component conceptualization. Journal of Applied Psychology, 78(4), 538.

Moradi, L., Mohamed, I., \& Yahya, Y. (2018). The Effect of Organizational Commitment and E-training on E-tourism Job Performance. International Journal on Advanced Science, Engineering and Information Technology, 8(6), 2286-2293.

Moses, S. N., Ostreicher, M. L., \& Ryan, J. D. (2010). Relational framework improves transitive inference across age groups. Psychological Research PRPF, 74(2), 207-218.

Mowday, R. T., \& Steers, R. M. (1979). Measurement of organizational commitment. Journal of Vocational Behavior 14: 224-247.

Myers, K. K., \& Sadaghiani, K. (2010). Millennials in the workplace: A communication perspective on millennials' organizational relationships and performance. Journal of Business and Psychology, 25(2), 225-238.

Ng, T. W., \& Feldman, D. C. (2011). Affective organizational commitment and citizenship behavior: Linear and non-linear moderating effects of organizational tenure. Journal of Vocational Behavior, 79(2), 528-537.

Nick, O. (1990). Work rewards, work values and organizational commitment in an employee-owned firm: Evidence from U.K. Human Relations 43(6): 513-526.

Parry, E., \& Urwin, P. (2011). The impact of generational diversity on people management. In Managing an age-diverse workforce (pp. 95-111). Palgrave Macmillan, London.

Parment, A. (2011). Generation $Y$ in consumer and labour markets (Vol. 15). Routledge. 
INTERNATIONAL JOURNAL OF ACADEMIC RESEARCH IN ACCOUNTING, FINANCE AND

MANAGEMENT SCIENCES

Vol. 11, No. 3, 2021, E-ISSN: 2225-8329 @ 2021 HRMARS

Pretti, T. J., \& McRae, N. (2021). Preparing Gen Y and Z for the Future of Work Through Co-operative Education: A Case Study on the University of Waterloo. In Applications of Work Integrated Learning Among Gen Z and Y Students (pp. 94-118). IGI Global.

Queiri, A., Yusoff, W. F. W., \& Dwaikat, N. (2015). Explaining generation-Y employees' turnover in Malaysian context. Asian Social Science, 11(10), 126.

Rasip, O. M., Muslim, N., Basir, S. A., Sulong, R. H., \& Bawadi, M. H. (2020). The Relationship between Work Values and the Staff Behaviour in Islamic-based Higher Learning Institutions in Malaysia. Universal Journal of Educational Research, 8(4), 1542-1548.

Roebuck, D. B., Smith, D. N., \& El Haddaoui, T. (2013). Cross-generational perspectives on work-life balance and its impact on women's opportunities for leadership in the workplace. Advancing Women in Leadership Journal, 33, 52-62.

Sheahan, P., \& Sheahan, P. (2005). Generation Y: Thriving and surviving with generation Y at work (pp. 72-77). Prahran: Hardie Grant Books.

Solnet, D., \& Hood, A. (2008). Generation Y as hospitality employees: Framing a research agenda. Journal Of Hospitality and Tourism Management, 15(1), 59-68.

Super, D. E., \& Mowry JR, J. G. (1962). Social and personal desirability in the assessment of work values. Educational and Psychological Measurement, 22(4), 715-719.

Twenge, J. M., Campbell, S. M., Hoffman, B. J., \& Lance, C. E. (2010). Generational differences in work values: Leisure and extrinsic values increasing, social and intrinsic values decreasing. Journal of Management, 36(5), 1117-1142.

Vveinhardt, J., \& Foktas, P. (2020). Effect of values congruence: are there any reasons to know values of different generations better? In Eurasian Business Perspectives (pp. 47-63). Springer, Cham.

Wey-Smola, K., \& Sutton, C. D. (2002). Generational differences: Revisiting generational work values for the new millennium. Journal of Organizational Behavior, 23(4), 363-382.

Weyland, A. (2011). Engagement and talent management of Gen Y. Industrial and Commercial Training, 43(7), 439.

Williams, K. C., \& Page, R. A. (2011). Marketing to the generations. Journal Of Behavioural Studies In Business, 3(1), 37-53.

White, C. (2006). Towards an understanding of the relationship between work values and cultural orientations. International Journal of Hospitality Management, 25(4), 699-715.

Wright, T. A. (1997). Job performance and organizational commitment. Perceptual and Motor Skills, 85(2), 447-450.

Yang, S. B., \& Guy, M. E. (2006). GenXers versus boomers: Work motivators and management implications. Public Performance \& Management Review, 29(3), 267-284.

Zedeck, S., Middlestadt, S., \& Hayes, E. (1981). Police work values: A comparison of police science students and current officers. Journal of Occupational Psychology, 54(3), 187-194. 